\title{
Sustainable Livelihoods of Fishermen Households Headed by Women (Case Study in Riau Islands Province of Indonesia)
}

\author{
Khodijah $^{1}$ \\ ${ }^{1}$ Department of Aquatic Resources Management, Faculty of Marine and Fisheries, Raja Ali Haji Maritime \\ University, Tanjungpinang, Indonesia \\ Correspondence: Khodijah, Department of Aquatic Resources Management, Faculty of Marine and Fisheries, \\ Raja Ali Haji Maritime University, Tanjungpinang, 29112 Riau Islands Province, Indonesia. Tel: 62-8-1980-5778. \\ E-mail: khodijah5778@gmail.com
}

\author{
Received: December 29, 2013 Accepted: February 24, 2014 Online Published: April 29, 2014 \\ doi:10.5539/ass.v10n9p187 \\ URL: http://dx.doi.org/10.5539/ass.v10n9p187
}

\begin{abstract}
The number of fishing households headed by women continues to show improvement in the last decade. In Riau Islands Province Indonesia, showed more than $80 \%$ are coastal villages with most of the poor people, and more than $50 \%$ of the poor are women who are vulnerable social economic will be head of household. This study focuses on five dimensions of livelihood assets to find the status of sustainability. The questionnaire survey addressed to 29 fishermen households headed by women from 300 fishermen households in the Malangrapat village. The results of this study highlight how the dimensions of personal leadership assets showed the main actors to influence the sustainable livelihoods in fishing households headed by women. Strengths of personal and leadership assets of women in the household could be an important factor to consider in agricultural development and fight against poverty in the rural areas, because by having good personal leadership they have a strong motivate to get out of poverty through women. This showed by the index of the personal and leadership assets dimensions of sustainable enough (60.34 and 71.93), while the other dimension does not show sustainability; social assets (26.87), human resources assets (27.59), financial assets (31.86), and physical assets (36.38).
\end{abstract}

Keywords: assets, poverty, fishermen households headed by women, sustainable livelihoods

\section{Introduction}

Key of the sustainability science is the dynamic interactions between nature and humans. Substantial understanding about the interactions met in recent decades include how human actions on the environment and human impact on the environment, because it is the study of social and development fields wanted to clarify this situation and appeared more interdisciplinary research (Kates et al., 2001).

In Asia, poverty described mostly are women, most of them lead households, without owning the land, moving, sometimes they are socially excluded and as fishermen in the coastal areas, almost all of Asia they rely on natural resources to build and develop livelihoods (IFAD, 2002) and poverty can begin at home (Chant, 2007). Therefore, the policy of sustainable development, households headed by women now becomes a contemporary issue and crucial (Lin, 2011). Proved in the last decade occurred tendencies increase in the number of households headed by women (Howard, 2007; Sumner, 2011), such as in Indonesia from $12.9 \%$ in 2007 to $13.91 \%$ in 2011 (KP3ARI, 2011) and 12.03\% of women in social-economically vulnerable are in the rural areas (TNP2K, 2012), even for the age group $45-59$ years, there were more than $50 \%$ of poor women social-economically vulnerable as head of household (BP2KS, 2012) and 43\% work in the agricultural sector (PEKKA, 2012). It means the higher the number of poor people in rural areas, the higher the number of women's social-economically vulnerable as head of household. It would be serious social-economic problems in Indonesia, because until 2013, the BPS data (BPS, 2013) show the number of poor is much higher in rural than urban areas with a ratio of $14.32 \%: 8.39 \%$ the issue is how the poor household livelihoods could sustained (Messer \& Townsley, 2003). This study is a collaborate of some of the previous livelihood framework concept as used by DFID, UNDP and CARE'S into a specific context, namely the fishermen households headed by women in the coastal villages. 


\section{Literature}

\subsection{Sustainable Development Approach}

Sustainability defined as how the interaction of social and natural systems, how these reactions affect the sustainability challenges that can meet the needs of current and future generations while substantially reducing poverty and preservation plan as a life-support system (Kates, 2011). Sustainable livelihoods in detail consist of: 1) they are able to cope with and recover from shocks and stress through coping strategies and adaptation; 2) economically effective; 3) ecological, ensuring that livelihood activities do not degrade the natural resources in a particular ecosystem; 4) social justice, which suggests that the promotion of livelihood opportunities for the group did not close the option for other groups, either now or in the future (Krantz, 2001).

To be sustainable, a livelihood made addressed at the level of households and communities, this is important in social equality in getting livelihood opportunities so evenly distributed among households. Even as the anti-poverty approach, sustainable livelihoods philosophy focuses on women (women centered), empowerment, explores what created the women's vulnerability on a macro level and analyze women asset at the micro level (activist on two levels), committed to the long-term results, by identifying livelihood assets in order for women to get out of poverty (Murray \& Ferguson, 2002).

There are three reasons why to support the sustainable livelihood approach to households headed of women; 1 ) households headed of women are not quite able to help from the growth and economic expansion in the region, 2) poverty faced by households headed by women can only be understood by women it self is not just a matter of income but other dimensions include feelings of helplessness, 3) Women are more know how the situation, condition and their needs, so they are important involved. So that the livelihood assets that need made analyzed adapted to the situation and needs of women themselves. According to Stevens (2010), "if women were in more productive and decision-making roles, we could be moving faster and more assuredly towards sustainability in the economic, social and environmental sense. Sustainable development is a political concept because it is about good governance, which will be hard to achieve until we get closer to gender parity" (p. 7).

Sustainable livelihoods framework, further highlights the assets than income, show an overview of poverty as limited ability of people or households that shows the vulnerability system, the trends and shocks of life (Murray \& Ferguson, 2001). Asset is sections that build sustainable livelihoods at the level of people, households and communities which divide into 5 sections (Murray \& Ferguson, 2002), namely: 1) Social assets. These assets made to the social connections that illustrate how women can do their goals, 2) Physical assets. Physical assets include women's basic needs for housing and food, as well as access to services and information to develop livelihood, 3) Human resource assets. Assets show at how women can work associated with the skills, knowledge, education and leadership 4) Personal assets. Personal assets are assets that connect the women's feelings of personal with cultural identity. These assets include self-confidence, self-esteem, motivate, and the other strength of women who bring to the process of personal transformation, 5) Financial assets. Financial assets are revenue, money and financial security (including access to finance from the government).

\subsection{Poverty and Sustainable Livelihoods}

According to Murray \& Ferguson (2002) to build a livelihood strategies be required service and opportunities, and the chosen strategy will be reason of livelihood outcomes. Poverty is important to be promoted by wider contextual factors, therefore for the female household needed a dual strategy through programs to intervention is practical interventions and strategic intervention. Practical interventions are working directly with women to build assets and reduce vulnerability. While strategic intervention is working at the policy level to change the context of vulnerability and reduce the conditions that make women vulnerable to poverty. According to Krantz (2001) intervention strategies focused on empowerment as a basis dimensional approach. Empowerment is personal empowerment and social empowerment. Personal empowerment refers to the increase in the confidence and skills of the people (human capital) to overcome obstacles, especially in the economic field. Social empowerment refers to the formation or strengthening of representative community-based organizations. Intervention programs to combat poverty in fisheries development continue be implemented, but poverty still dominate the fishermen households. According to Lin (2011) has become a common characteristic of poverty in female-headed households, and this is the crucial issue of contemporary and current. The female-headed households are households with a female head of household as either not married, uncertain, divorced or widowed (BPS \& BAPPEDA Kepri, 2010; PEKKA, 2012; Chant, 2003). Difficulties and economic pressures on poor households in coastal areas can lead to limited life choices, more attention to how the family can survive without considering how future life. 


\section{Method}

\subsection{Research Methods}

This study is a qualitative research conducted using an exploratory research method. Qualitative research to understand the actions recommended in people for the challenges in their daily work, and the coping strategies, especially in women (Sidloyi, 2010). Based on the research goals be achieved, this study using a case study approach and survey methods. The case study is a study that explores the problem with detailed restrictions, has deep data collection (qualitative) and includes a variety of resources (Sugiyono, 2008; Yin, 1981: 1989) will be required in the survey method of collecting primary data using questionnaires to get quantitative data (Singarimbun \& Efendi, 1989).

This study taken place in the village Malangrapat determined purposive. There are several considerations chose the village Malangrapat namely 1) located in the Riau Islands province with the largest number of islands in Indonesia (2,408 islands), 2) Bintan Island is an area of free trade zones and special economic zone bordering Singapore and Malaysia , 3) Malangrapat village has the largest area of land and the longest coastline in the Riau Islands,3) More than $80 \%$ of households in the village Malangrapat a fisherman household. Under this map of the site study (see Figure 1).

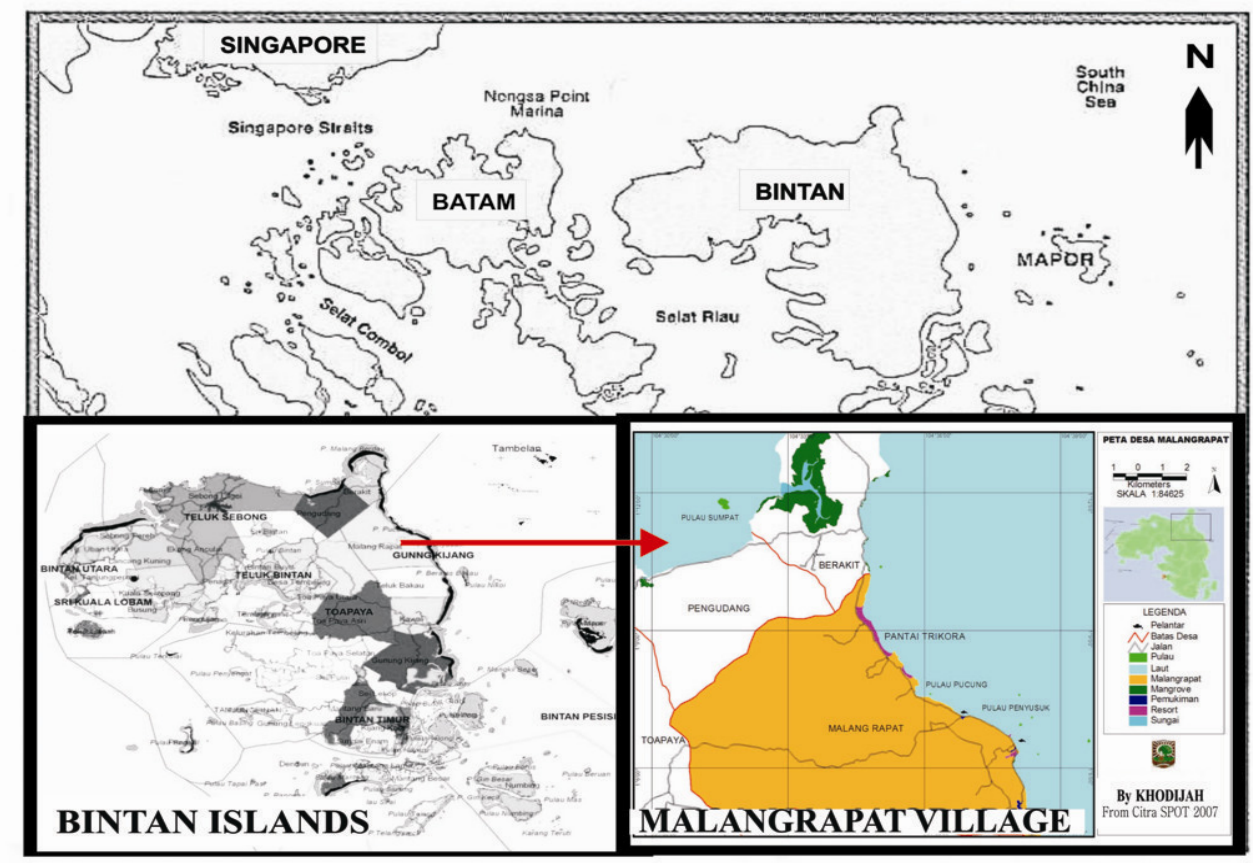

Figure 1. Map the location of the research

\subsection{Sampling Methods}

The population is all households that meet the sampling criteria, and the sample is households that meet the sampling criteria and used as the unit of analysis in this study. Determination of sample households used the unit of analysis studies using non probability sampling method with purposive sampling type, the purpose that the primary data collection researchers are more flexible to decide what techniques will used (Moleong, 2001).

The sampling criteria were used as a household unit of analysis is the entire household, including households headed by women and fishermen who settled in the village of Malangrapat. Respondents in this study were all female-headed households in the village fishermen Malangrapat. Female heads of households are women who are part of a household who is responsible for the basic needs, and or / appointed as the head. Based on the results of direct data collection by researchers note the number of fishermen households totaled 300 households, and 300 households are becoming eligible households headed by women are 29 households $(9.67 \%)$ and total study respondents used because it meets the criteria of sampling.

\subsection{Data and Analysis}

The data collected in this study is primary data and secondary data corresponding research goals be achieved. 
The primary data obtained by tracking the village, participating observation and interviews. While secondary data using library research methods, in this study both early and advanced information related to the research. The instrument used for data collection was a questionnaire prepared by the likert scale.

There are several stages of data analysis used: 1) Collect, describe and document the raw data. This phase requires data collection, management and interpretation. The data obtained grouped into two parts, namely quantitative and qualitative data, 2) Identification and categorization of descriptors and components. Quantitative data has arranged in Microsoft excel do the tabulate classification code data into categories and calculated the average value of each dimension and attribute groups that has defined, 3) Patterns and contextual analysis done by examining the data and show similarities and differences in contextual meaning repeated. Research informants where may to confirm that the researchers interpretation is consistent with the life and livelihood of the research object, 4) The last stage requires a synthesis of research data into the main theme so that conclusions be drawn, and decisions made about the required action.

Analysis to decide the status of the six livelihood dimensions of sustainable livelihood (Social, Physical, Financial, Human Resources, Personal and Leadership) fishing households headed by women done as follows:

The analysis step for determining the status of sustainable livelihood assets through the following stages:

1) Index calculation (Cahyat et al. 2007). Index calculation done by normalizing the data, with the following steps:

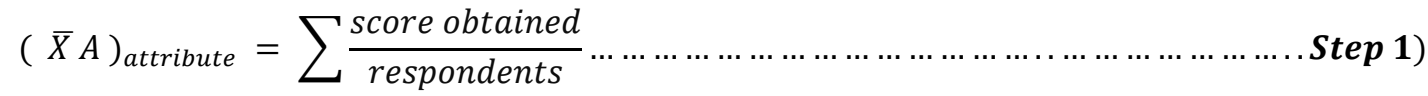

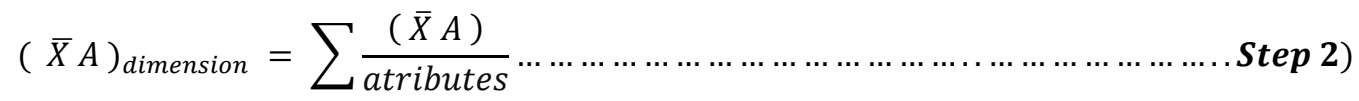

$$
\begin{aligned}
& \text { Sustainability Index } \left.=\sum \frac{(\bar{X} A)-\text { score minimum }}{\text { score maximum }- \text { score minimum }} \ldots \ldots \ldots \ldots \ldots \ldots \ldots \ldots \ldots \ldots \text { Step } 3\right)
\end{aligned}
$$

2) Sustainability Status Determination. Sustainability index scale lays between 0-100, then by using Microsoft Excel program, the sustainability index visualized with radar diagrams.

Table 1. Index Category and sustainability status

\begin{tabular}{ccc}
\hline Index Value & Index Category & Sustainability Status \\
\hline $00.00-25.00$ & Bad & Unsustainable \\
$25.01-50.00$ & Less than satisfactory & Less sustainable \\
$50.01-75.00$ & Satisfactory & Sustainable enough \\
$75.01-100.00$ & Good & Highly sustainable \\
\hline
\end{tabular}

3) Determination of dimensions of potential Livelihoods Assets. The analysis stage using the "centrality and power analysis" by analysis tools such as UNICET software, version 6.85 (Borgatti at al., 2002), this software is a comprehensive program that is often used to analyze social network data and other data and most appropriately used in the analysis of sustainability. The data used in this analysis is the score value from a qualitative scale from poorly defined (1) to good (4). Output analysis results visualization Net Draw shaped (Hanneman et al, 2005).

\section{Results}

\subsection{Characteristics of Fishermen Household Headed by Women}

Criteria referred to women heads of households are women who are part of a household that is permanently responsible for the daily needs of the household due to the inability to live without a spouse or partner (divorced, widowed and unmarried or considered / appointed as the head, (Hussain \& Huda, 1995; BPS \& BAPPEDA Kepri, 2010; PEKKA, 2012; Chant, 2003; Ferial, 2010; Drago et al., 2004).

Further, from 29 households established, the results of the survey showed that $72 \%$ of who are widows whose husbands died, $21 \%$ abandoned, $4 \%$ unmarried and 3\% divorced. All heads of households are in the productive age group is $58.62 \%$ (51-65 years) and $41.38 \%$ (20-50 years) with $62 \%$ of them just graduated from elementary 
school, 28\% not school, 4\% junior high school, 3\% senior high school and 3\% higher education high school. And education level for household members relative of low: not school (men 72,72\% and women 39,13\%), elementary school (men 9,09\% and women 13,04\%, junior high school (men 18,18\% and women 34,78\%), senior high school (men $0 \%$ and women 13,04\%).

\subsection{Sustainable Assets of Fishermen Household Livelihood Headed by Women}

All assets dimension of fishermen household livelihood headed by women of Malangrapat village, the data showed relatively low and unsustainable. Each of those livelihood assets dimension (see Figure 2) which known to have personal and leadership assets as the only asset that has status of quite sustainable, while the dimensions of social, human resources, financial and physical status are less sustainable.

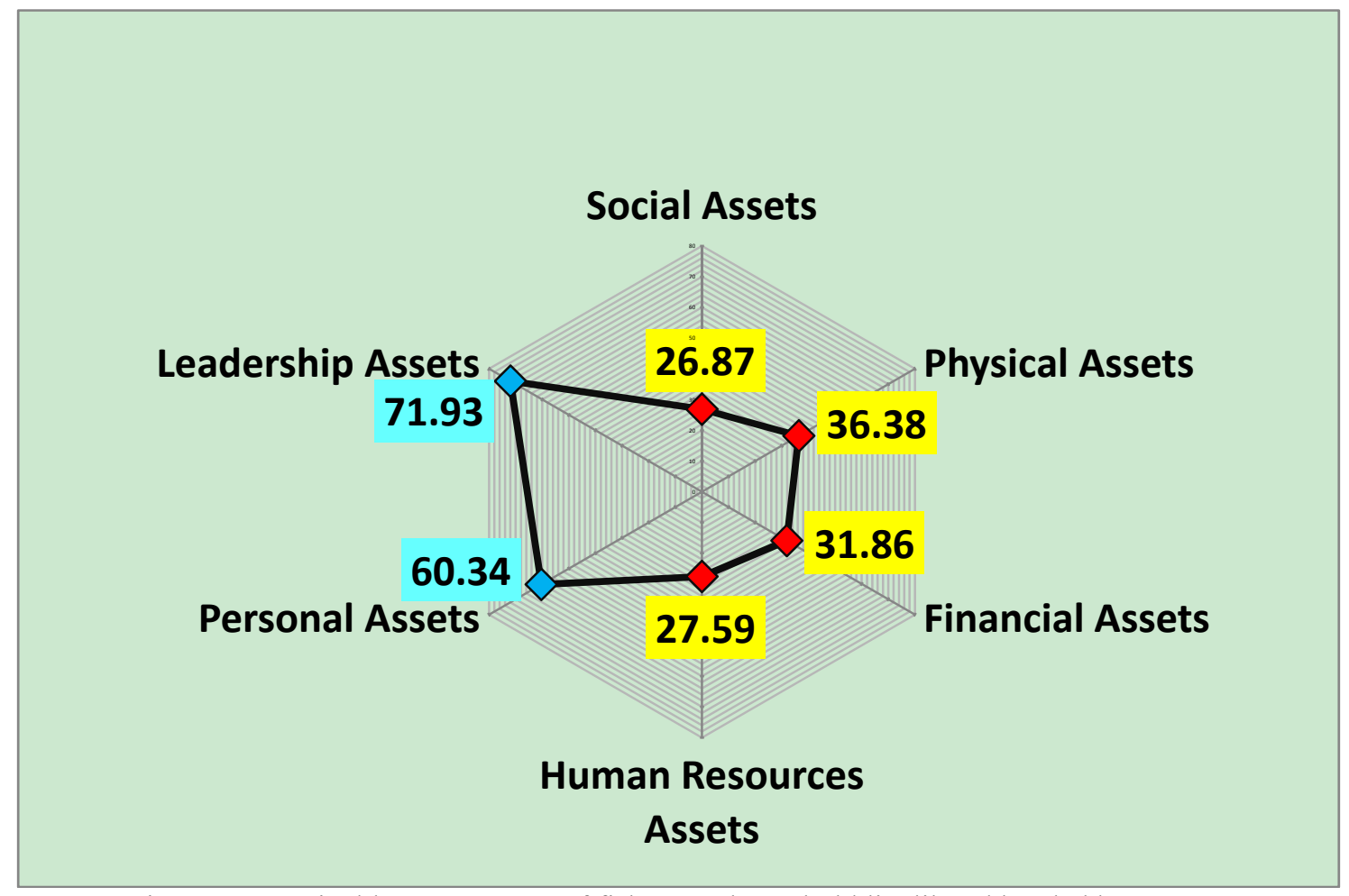

Figure 2. Sustainable assets status of fishermen household livelihood headed by women

Sustainability dimensions of personal assets seen from two attributes, namely: a) Confidence (PA1), b) motivate (PA2), autonomy (PA3), self-esteem \& assertiveness (PL4), d) freedom (PL5), e) balancing work and personal life (PL6). Attributes that most support personal assets of sustainability livelihood are autonomy and motivate (see symbol PA2 with index 3,0 and PA3 with index 3,6 from Figure 3 below). Sustainability dimensions of leadership assets seen from five attributes namely: a) lead the family (LA1), b) earn a living (LA2), c) educate (LA3), exemplary (LA4) and care of the household (LA5). The strength of personal leadership dimensions visualized with strengths main line (thick stripes) of Figure 4. Analytical results Software Package of the Social Network analysis version 6.85 that used to find the main actors of livelihood assets dimension and highly influential on other livelihood assets dimension can visualized in the following figure (see Figure 3). 


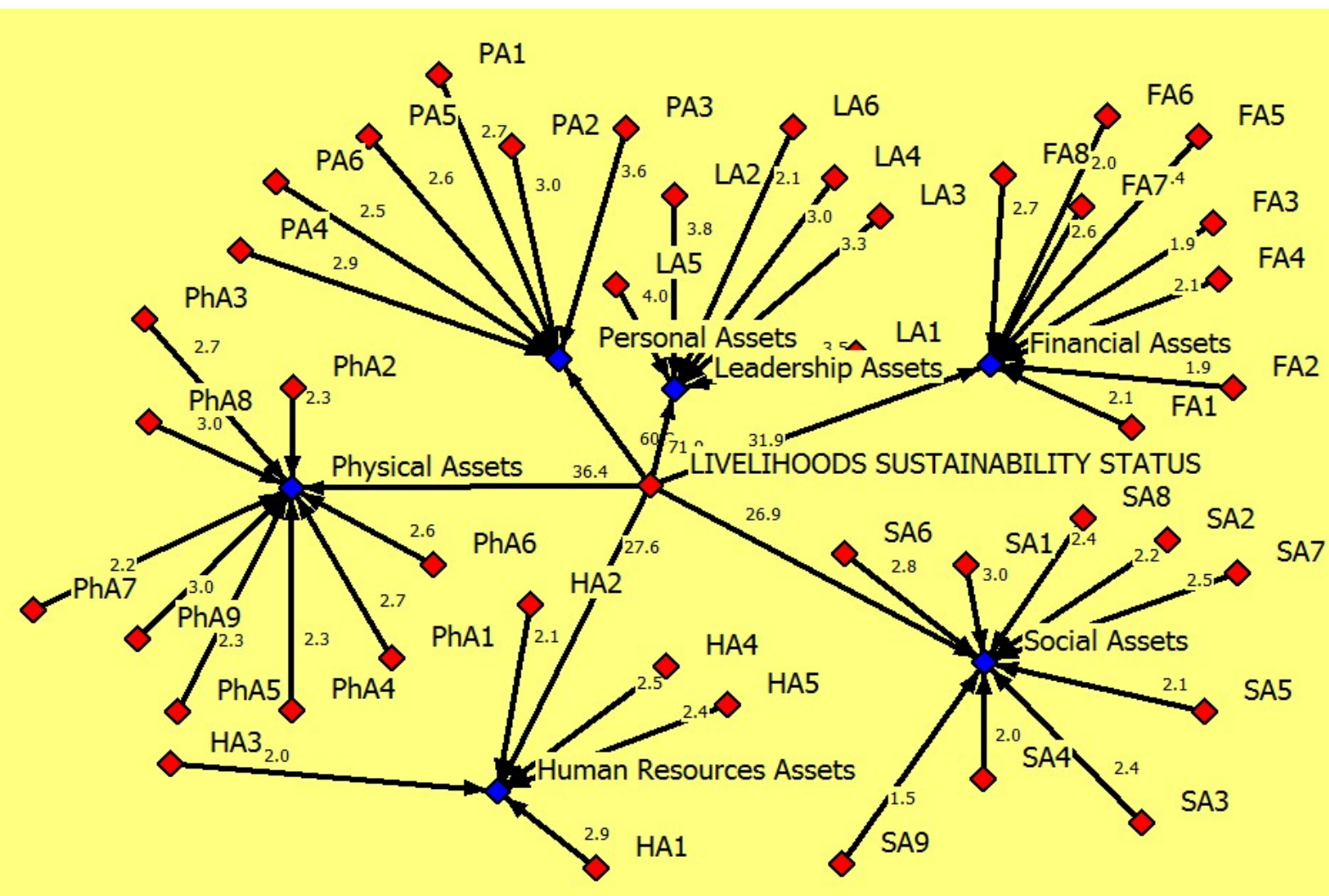

Figure 3. Visualization of dimensions and attributes (Net-Draw) that effect sustainability

Description: SA (Social Assets), PhA (Physical Assets), FA (Financial assets), HA (Human Assets), PA (Personal Assets), LA (Leadership Assets).

\subsection{Leadership Personal Assets as Main Actor of Sustainable Livelihoods Establishment}

To explain sustainability, required multiple disciplines (Kates et al., 2001) and to make sustainability not only have to focus on the spectrum of concerns with environmental issues, socio-economic and social quality of life issues, but we also have to meet a real shift in values, attitudes, and pro-environmental behavior (PEBS) which sustainable and a community lifestyle (Pelletier, 2011). Therefore to explain poverty, gender and women, personal assets is one of the important dimensions of sustainable livelihood assets (IFAD, 2002), even according to (Murray \& Ferguson, 2002), personal asset is the strength of women, which led to the process of personal transformation, as proposed by (Utami et al., 2010) that the increase in self-esteem of women after obtaining ACCESS intervention program in South Sulawesi can affect women's leadership and participation. According to (Heller, 2003), participation is important because it can lead to better use of human resources, which will improve earnings. The results of this study found that the strengths the attributes of personal dimension is personal leadership of women in the household. The strength of personal leadership of women as heads of households were able to support the sustainability livelihoods of household. However, because these power rarely get attention from outsiders their lives difficult to move out of poverty. Overall dimensions of livelihood assets that have the attributes and the lowest values indicating low support for female heads of households in coastal villages are information: see LA6 symbol from Figure 3 (security and protection to the family). Various programs of government intervention in the village but the information is not socialized evenly until the intervention program does not touch the female-headed households.

In the context of agricultural development, involve of women in the development process important to improve the welfare of the household. But in reality, especially in poor households is very difficult to take part and their point of view difficult-represented. Such as those met in the village Malangrapat, despite having a good personal assets but they still find it difficult to take part in the development process in the village, so most of them live in poverty. Therefore, the context of agricultural development the future, make sustainable livelihoods and reduce poverty the power of personal leadership assets of women is an important issue that must consider. 
There are two approaches that must be done for the above purpose, namely internal and external approach. Internal approach in question is a leadership personal asset optimization, by strengthening the "self-efficacy", while the external approach that need government intervention to promote "learned helplessness" with empowerment programs. Self-efficacy is a person's judgment about his ability to do certain activities. According to (Narayan et al., 2000) there is a risk for people with low social capital because they feel that they can't give to the discussion, so that 'important message of poverty' they are not included in development work. Many studies show that the relationship between self-efficacy and self-esteem to the welfare, among others, the difference in self-efficacy and self-esteem among women working and not working. Self-efficacy of women working (included) is higher than women who do not work (not included), so it can also be concluded that there is a strong relationship between self-efficacy with welfare (Sahoo \& Rath, 2003), thus, for self-efficacy and self-esteem of women who married and work (Sadeghi \& Vasudeva, 2006). Different employment status (professional, non-professional and unemployed women) showed differences in self-efficacy and self-esteem is much different, where women with professional jobs have higher value of self-efficacy and self-esteem than unemployed women. So that self-efficacy is described as a catalyst for increased prosperity. Individuals who have high belief in self-efficacy and self-esteem, can produce strong feelings for prosperous.

Related context of leadership personal assets, something needed in life skills a person to show sustainable livelihoods is the soft skills. According to (Elfindri et al., 2010) the soft skills are communication skills, group skills, ethics and moral and spiritual skills. Klaus (2007) mentioned something that can bring soft touch to the soft skills to promote themselves, necessary 'branding and bragging'. Branding is a picture that appears to people thinking of us, while bragging is the most powerful tool to convey a message about our branding. Besides efforts to promote itself through the strengthening of personal assets internally above, is also required government intervention to promote helplessness fishermen households headed by women through empowerment efforts. As expressed by Petersen et al., 1993 in Franzoi (2003), that the people who experience disability, able to affect their own lives, the growing despair and passive attitude, and they will stop engaging in activities that could make their lives better.

By having a good personal leadership assets, expected to: a) reduce risk of the low of human resources assets of fishing households headed by women such as the character and behavior could so influential women in the culture of any organization, b) increase productivity, due to personal competence strong leadership they will motivate themselves, willing to work hard, keep up a positive attitude and develop good social relationships with various parties.

So the power of the leadership personal assets within the framework of agricultural development and success of various government development interventions can expanded through increased personal leadership skills every device of government or facilitator involved in development programs implementation, especially in rural areas. The strength of personal leadership is an important part of the assets of personal assets that become important findings in this study. Because the results of this study contribute new knowledge through the approach of the livelihood assets, personal assets which can be key to the success of poverty reduction efforts. Even to the level of household personal assets to be key to the sustainability of household livelihoods. Special fishing households headed by women personal assets owned women as heads of households were able to sustain the livelihood of the household for the better. Therefore, government attention through appropriate interventions, the potential personal assets will be able to create sustainable livelihoods and agricultural development success.

\section{Conclusion}

Various poverty alleviation efforts that promoted during this time are not yet able to offer a significant impact to sustainable prosperity, especially for fishermen households. One dimension which is very rarely discussed within the framework of agricultural development is the power of leadership personal assets. Results of this observation showed a significant relationship between the leadership personal assets with status of the sustainable livelihoods household's of fishermen, where of several dimension of livelihood assets that most influence a sustainable status is a leadership personal asset. It's concluded that the failure of various empowerment programs because it is not supported by the power of leadership personal assets. So, it is necessary for consider leadership personal asset into an early priority before making an effort for other livelihood assets mainly within the framework of sustainable agricultural development.

\section{Acknowledgements}

The authors would like to thanks to Professor Elfindri (Promotor) and Professor Rahmat Syahni and Dr. Alfian Zein (Co-Promotor) and Prof. Yonariza, Prof. Rudi Febriamansyah and Dr. Endry Martius who guided and gave me many advices and recommends in writing a dissertation. This article is part of my dissertation. The views 
presented here response of the author.

\section{References}

Arikunto, S. (2005). Manajemen Penelitian. Jakarta, Indonesia: Penerbit Rineka Cipta.

Badan Pendidikan dan Penelitian Kesejahteraan Sosial. (2012). Kementerian Sosial Dalam Angka. Pembangunan Kesejahteraan Sosial. Jakarta: BP2KS. Kementerian Sosial Republik Indonesia. Pusat Data dan Informasi Kesejahteraan Sosial. Retrieved from http://www.kemsos.go.id

Borgatti, S. P., Everett, M. G., \& Freeman, L. C. (2002). Ucinet for Windows: Software for Social Network Analysis. Harvard, MA: Analytic Technologies.

Cahyat, A., Gönner, C., \& Haug, M. (2007). Mengkaji Kemiskinan dan Kesejahteraan Rumah Tangga. Sebuah Panduan dengan Contoh dari Kutai Barat Indonesia. Bogor: CIFOR.

Chant, S. (2003). Female Household Headship and the Feminisation of Poverty: Facts, Fictions and Forward Strategies. LSE Gender Institue: New Working Paper Series, Issue 9 (London: London School of Economics). Retrieved from http:/www.lse.ac.uk/genderInstitute/pdf/femaleHouseholdHeadship.pdf

Chant, S. (2007). Poverty Begins at Home? Questioning some (mis) Conceptions About Children, Poverty and Privation in Female-Headed Households. Revised paper for UNICEF Report on State of the World's Children 2007. Retrieved from http://www.unicef.org/sowc07/docs/chant.pdf

Drago, R., David, B., \& Mark, M. (2004). Female Breadwinner Families: Their Existence, Persistence and Sources. The Institute for the Study of Labor (IZA) in Bonn Germany. September 2004. IZA Discussion Paper. No. 1308. Retrieved from http://ftp.iza.org/dp1308.pdf

Elfindri, Rumingan, J., Wello, M. B., Tobing, P., Fitriyanti, Eriyani, Z. E., \& Indra, R. (2010). Soft Skill Untuk Pendidik. Jakarta: Penerbit Baduose Media.

Ferial, K. (2010). Female Headed Households in the West Bank and Gaza Strip. An Inside Perspective into their Socioeconomic Conditions and Their Experience of Being Female Heads. Retrieved from http://www.pwrdc.ps/site_files/FHH21March Final for website.pdf

Franzoi, S. L. (2003). Social Psychology (3rd ed.). New York: McGraw-Hill.

Hanneman, R. A., \& Riddle, M. (2005). Introduction to social network methods. Riverside, CA: University of California, Riverside. Retrieved from http://faculty.ucr.edu/ hanneman/

Heller, F. (2003). Participation and Power: A critical Assessment. International Association for Applied Psychology, 52(1), 144-163. http://dx.doi.org/10.1111/1464-0597.00128

Howard, T. (2007). The Effects of Poverty on Female-Headed Households. Social Work Program Spring 2007. SOCW 376 [PowerPoint slides]. Chattanooga BSW: University of Tennessee. Retrieved from http://thoward0927.pbworks.com/f/poverty powerpoint.ppt

Hussain, N., \& Huda, S. (1995). Problems of the Women Headed Households. Bangladesh. Working Paper Number 9. The BRAC-ICDDR,B Joint Research Project Dhaka. Retrieved from http://www.bracresearch.org/workingpapers/Working_Paper_9.pdf

International Fund for Agricultural Development. (2002). Assessment of Rural Poverty. Asia and the Pacific: IFAD. Retrieved from http://www.ifad.org

Kates, R. W. (2011). What kind of a science is sustainability science? Proceedings of the National Academy of Sciences, 108(49\&99), 19449-19450. Retrieved from http://www.rwkates.org

Kates, R. W., Clark, W. C., Corell, R., Hall, J. M., Jaeger, C. C., Lowe., ... Svedin, U. (2001). Sustainability science. Science, 292, 641-642. Retrieved from http://www.rwkates.org http://dx.doi.org/10.1126/science.1059386

Kementerian Pemberdayaan Perempuan dan Perlindungan Anak Republik Indonesia. (2011). Profil Perempuan Indonesia. Jakarta: KP3AI. Retrieved from http://menegpp.go.id/V2/index.php/daftar-buku/ profil-perempuan

Klaus, P. (2007). The Hard Truth about Soft Skill. New York: Collins Business Publishers.

Krantz, L. (2001). The Sustainable Livelihood Approach to Poverty Reduction. An Introduction. Stockholm, Sweden: Swedish International Development Cooperation Agency (SIDA). Retrieved from http://www.sida.se 
Lin, X. C. (2011). Female Heads of Households in Eurasian Societies. Taipei and Rotterdam in times of industrialization. (Doctoral dissertation, Universiteit Nijmegen, Taiwan, 2011). Retrieved from http://hdl.handle.net/2066/91256

Messer, N., \& Townsley, P. (2003). Local Institutions and Livelihoods: Guidelines for analysis. Rome: Rural Development Division Food And Agriculture organization of The United Nations.

Moleong, L. J. (2001). Metodologi Penelitian Kualitatif. Bandung: PT. Rosdakarya.

Murray, J., \& Ferguson, M. (2001, January). Women in Transition Out of Poverty. In C. Letemendía (Ed.), An asset based approach to building sustainable livelihoods. Women and Economic Development Consortium. Retrieved from http://www.canadianwomen.org/sites/canadianwomen.org/files/PDF\%20-\%20ED\%20 Resource\%20-WIT-asset.pdf

Murray, J., \& Ferguson, M. (2002, January). Women in Transition Out of Poverty. In C. Letemendía (Ed.), A Guide to Effective Practice in Promoting Sustainable Livelihoods through Enterprise Development. Women and Economic Development Consortium. Retrieved from. http://www.canadianwomen.org/sites/canadianwomen.org/files/PDF\%20-\%20ED\%20Resource-WIT-guide. pdf

Narayan, D., Chambers, R., Shah, M. K., \& Petesch, P. (2000). Voices of the Poor. Crying Out for Change. Madison Avenue, New York, N.Y: Oxford University Press. Retrieved from http://siteresources.worldbank.org/INTPOVERTY/Resources/335642-1124115102975/1555199-112411520 1387/cry.pdf http://dx.doi.org/10.1596/0-1952-1602-4

Pelletier, L. (2011). Personal Autonomy and Environmental Sustainability. Paper presented at the Department of Psychology Friday, February 18, 2011 at 11:00 a.m. - noon Concordia University MB Building, Room MB 6.2601450 Guy Street (de Maisonneuve Blvd. West). Retrieved from http://www.socialsciences.uottawa.ca/psy/professor-profile?id=233\&pageID=2

Pemberdayaan Perempuan Kepala Keluarga. (2012). Sepuluh Tahun PEKKA. Laporan PEKKA. Desember 2001-Desember 2011. Jakarta: PEKKA. Retrieved from http://www.pekka.or.id

Sadeghi, A. I. A. \& Vasudeva, P. (2006). Self-Efficacy and Self-esteem: A Comparative Study of Employed and Unemployed Married Women in Iran. Reprinted from the German Journal of Psychiatry. Germany: Dept. of Psychiatry, The University of Göttingen. Retrieved from http://www.gjpsy.uni-goettingen.de/gjp-article-sadeghi.pdf

Sahu, F. M., \& Rath, S. (2003). Self-efficacy and Wellbeing in Working and Non-working Women: The Moderating Role of Involvement. Psychology and Developing Societies, 15(2), 187-200. Retrieved from http://pds.sagepub.com/content/15/2.toc

Sidloyi, S. (2010). Survival Strategies of Elderly Women in Female-Headed Households. The Faculty of Humanities Univesity of Pretoria, Univesity of Pretoria (Master's thesis). Retrieved from http://upetd.up.ac.za/thesis/available/etd-05112011-134407/unrestricted/dissertation.pdf

Singarimbun, M., \& Efendi, S. (1989). Metode Penelitian Survei. Jakarta: Penerbit LP3ES.

Statistik, B. P. (2013, March). Profil Kemiskinan di Indonesia. Berita Resmi Statistik. No. 47/07/Th. XVI, 1 Juli 2013. Jakarta: BPS. Retrieved from http://www.bps.go.id/brs_file/kemiskinan_01jul13.pdf

Statistik, B. P., \& Pembangunan Daerah Kepulauan Riau, B. P. (2010). Kepulauan Riau Dalam Angka. Tanjungpinang, Kepulauan Riau: BPS dan BAPPEDA Kepri.

Stevens, C. (2010, April). Are Women the Key to Sustainable Development? In The Sutainable Development Insight, $003 . \quad$ Boston University. http://www.bu.edu/pardee/files/2010/04/UNsdkp003fsingle.pdf

Sugiono. (2008). Memahami Penelitian Kualitatif. Jakarta: Penerbit Alfabeta.

Sumner, C. (2011). Akses terhadap Keadilan: Pemberdayaan Perempuan Kepala Keluarga di Indonesia: Studi Kasus di Provinsi Nanggroe Aceh Darussalam, Jawa Barat, Kalimantan Barat, dan Nusa Tenggara Timur (Research Report of Australia Indonesia Partnership). Australia Legal Development Facility (IALDF) dan Australian Agency of International Development (AusAID). Retrieved from http://www.familycourt.gov.au/wps/wcm/resources/file/eb67980e098627f/Access_to_Justice_Bahasa.pdf

Tim Nasional Percepatan Penanggulangan Kemiskinan. (2012, December). Kumpulan Tanya-jawab 
Program-program Penanggulangan Kemiskinan. Cet 1 Desember 2012. Jakarta: Tim Nasional Percepatan Penanggulangan Kemiskinan (TNP2K). Sekretariat Wakil Presiden Republik Indonesia. Retrieved from www.tnp2k.go.id

Utami, B., Yusdjam, K., Pulu, L., \& Mushanif, S. (2010). Kepemimpinan dan Partisipasi Perempuan Dalam Membangun Kebijakan Publik Di Komunitas. Studi Kasus di Jeneponto (Sulawesi Selatan) dan Lombok Tengah (Nusa Tenggara Barat). In M. Yanti (Ed.), Laporan KAPAL Perempuan Seri Penelitian. Jakarta: Kerjasama KAPAL Perempuan, Australia Indonesia Partnership \& IDSS.

Yin, R. K. (1989). Case Study Research: Design and Methods. London: Sage Publication.

\section{Copyrights}

Copyright for this article is retained by the author(s), with first publication rights granted to the journal.

This is an open-access article distributed under the terms and conditions of the Creative Commons Attribution license (http://creativecommons.org/licenses/by/3.0/). 